\title{
Seasonal dynamics of the biogenic silica cycle in surface sediments of the Helgoland Mud Area (southern North Sea)
}

\author{
Till Oehler ${ }^{\mathrm{a}, *}$, Michael Schlüter ${ }^{\mathrm{a}}$, Ulrike Schückel ${ }^{\mathrm{b}}$ \\ ${ }^{a}$ Alfred Wegener-Institut für Polar- und Meeresforschung, 27570 Bremerhaven, Germany \\ b Senckenberg am Meer, Marine Research Department, Südstrand 40, 26382 Wilhelmshaven, Germany
}

\section{A R T I C L E I N F O}

\section{Article history:}

Received 13 January 2015

Received in revised form

21 July 2015

Accepted 23 July 2015

Available online 26 July 2015

Keywords:

Nutrient fluxes

Macrofauna

Silicic acid

In situ measurements

Benthic-pelagic coupling

\begin{abstract}
A B S T R A C T
In coastal waters and the ocean silicic acid $\left(\mathrm{Si}(\mathrm{OH})_{4}\right)$ is a key nutrient for primary producers (e.g. diatoms) and other siliceous organisms, because it is required for the formation of frustules and other hard parts made of biogenic silica (bSi). Especially in shallow waters like the southern North Sea, dissolution of bSi in surface sediments and the reflux of silicic acid from sediments into the water column is an important feedback mechanism for sustaining primary production. We investigated the temporal variability of benthic silicic acid fluxes and the recycling efficiency of bSi in surface sediments of the Helgoland Mud Area (southern North Sea). For this purpose we used different methods including a benthic chamber lander system for in situ flux studies of $\mathrm{Si}(\mathrm{OH})_{4}$, ex situ sediment incubations, pore water studies and sediment analysis. Our in situ measurements revealed considerable temporal variations with low silicic acid fluxes in winter $\left(0.3-1.0 \mathrm{mmol} \mathrm{m}^{-2} \mathrm{~d}^{-1}\right.$ in March 2013 and 2014), increased fluxes of 2.0-4.0 mmol m $\mathrm{mm}^{-2} \mathrm{~d}^{-1}$ in November 2013, and high fluxes in June and August 2012 (3.6-8.3 mmol m-2 $\mathrm{d}^{-1}$ ). The relevance of biological mediated transport for the recycling of $\mathrm{Si}(\mathrm{OH})_{4} \mathrm{was}$ underlined by comparing in situ and ex situ sediment incubations, pore water studies, as well as depth profiles of benthic macrofauna. Mass budget calculations indicate that about $1.7-2.2 \mathrm{~mol} \mathrm{bSi} \mathrm{m}^{-2} \mathrm{settle}^{-}$ annually at the seafloor, off which about $60-81 \%$ are recycled within surface sediments and transported back into the water column.
\end{abstract}

(c) 2015 Elsevier Ltd. All rights reserved.

\section{Introduction}

In aquatic environments, dissolved silicic acid $\left(\mathrm{Si}(\mathrm{OH})_{4}\right)$ is an important component with respect to primary production and considerations of food-web interactions. As a key nutrient it controls the growth of diatoms and is used by some sponges, radiolarians, silicoflagellates, species of choanoflagellates and potentially by picocyanobacteria (Tréguer and De La Rocha, 2013). These organisms produce amorphous biogenic silica (bSi), which serves primarily as structural material. The availability of $\mathrm{Si}(\mathrm{OH})_{4}$ in the water column is controlled by external sources (e.g. river runoff), uptake by siliceous plankton, as well as recycling of biogenic silica in the water column and surface sediments (e.g. Gehlen et al., 1995; Tréguer and De La Rocha, 2013). Biogenic silica is undersaturated with respect to $\mathrm{Si}(\mathrm{OH})_{4}$ concentrations in the water column or in pore waters of surface sediments (e.g. Hurd, 1973). Consequently, a significant part of bSi is dissolved during the transfer through the water column to the seafloor and in surface

\footnotetext{
* Corresponding author.

E-mail address: Till.Oehler@zmt-bremen.de (T. Oehler).
}

sediments. This causes rather low preservation and burial rates in sediments, compared to the rain rate of bSi reaching the seafloor (Dixit et al., 2001; Rickert et al., 2002; Tréguer and De La Rocha, 2013).

Comparing different regions of the world ocean, DeMaster (2002) identified largest long-term burial rates of bSi for continental margins, the North Pacific, the equatorial Pacific and the Southern Ocean. For example, biogenic silica contents of more than $70 \%$, silicic acid fluxes of $0.095-0.767 \mathrm{~mol} \mathrm{~m}^{-2} \mathrm{yr}^{-1}$ (Deep Sea) and burial rates of $>0.84 * 10^{12} \mathrm{~mol} \mathrm{yr}^{-1}$ were reported for the Southern Ocean (Schlüter et al., 1998; DeMaster, 2002; Geibert et al., 2005). Although for coastal regions like the Amazon Shelf or Monterey Bay high fluxes of $0.46 \mathrm{~mol} \mathrm{~m}^{-2} \mathrm{yr}^{-1}$ or $2.28 \mathrm{~mol} \mathrm{~m}^{-2} \mathrm{yr}^{-1}$ were observed (Tréguer and De La Rocha, 2013), still little is known about the benthic silica cycle in temperate coastal, shallow water environments. In these areas the benthic silica cycle varies over seasonal time scales, is closely coupled to processes in surface waters and is often affected by benthic macrofauna (Aller, 1980; Emerson et al., 1984; Ragueneau et al., 2002, 2005). After spring phytoplankton blooms benthic macrofauna can for example accumulate bSi in surface sediments due to filtration and biodeposits. In late spring and summer the 
delayed benthic efflux of silicic acid might in turn sustain primary production in the water column (e.g. Amo et al., 1997; Chauvaud et al., 2000; Ragueneau et al., 2002).

Considering the North Sea, the benthic silica cycle was studied by $e$. g. Helder and Andersen (1987), Rutgers van der Loeff et al. (1980), Vanderborght et al. (1977), Ehrenhauss et al. (2004), Gehlen et al. (1995), Nedwell et al. (1993) or Raaphorst et al. (1990). Most of the data sets were derived for the Wadden Sea, whereas only a few studies considered permanently water covered regions of the southern North Sea (e.g. Gehlen et al., 1995). These data sets were derived by ex situ incubation experiments or ex situ pore water studies. Investigations of benthic fluxes by in situ techniques like benthic lander systems, a prerequisite for precisely quantified benthic nutrient fluxes (Viollier et al., 2003; Hammond et al., 2004), are still limited for the North Sea. Such in situ studies mainly addressed the quantification of the sediment oxygen demand in the North Sea (Forster et al., 1999; Ståhl et al., 2004; Janssen et al., 2005).

We considered the benthic silica cycle in the southern North Sea, by in situ and ex situ studies of benthic fluxes as well as by pore water and sediment investigations during several cruises with $R V$ Heincke in the years 2012-2014 (Table 1). Major objectives of our study were to identify temporal patterns of benthic fluxes, the recycling of bSi in surface sediments and the significance of biological mediated transport processes for the flux of $\mathrm{Si}(\mathrm{OH})_{4}$ through the sediment-water interface. Other nutrients (e.g. $\mathrm{NH}_{4}$, $\mathrm{NO}_{3}$ ) and carbon fluxes, as well as detailed analyses of benthic macrofauna are shown elsewhere (Oehler et al., accepted). Our study site (Fig. 1) represents an exceptional depositional environment with mostly fine grained sediments and hydraulic impermeable to semi-permeable sediments. We chose the Helgoland Mud Area because sediments are not frequently reworked and relocated by tidal currents and storms, as it is the case for most of the sandy sediments of the North Sea (Hebbeln et al. 2003). Therefore accumulated sediments and benthic nutrient fluxes reflect local processes in the overlying water column (e.g. primary production or particle export reaching the seafloor). Furthermore, the impermeable sediments are not affected by wave induced pore water flushing which narrows benthic transport processes to diffusion and to biological mediated transport. This allows us to estimate the impact of benthic fauna on pore water chemistry and benthic fluxes of silicic acid. Our results may support food web studies or ecological models, as we identified different time scales in which particulate and dissolved silica are transferred in between the benthic and pelagic environment.

\section{Material and methods}

\subsection{Study site}

For investigations of benthic fluxes in the southern North Sea, we selected the Helgoland Mud Area and its surroundings (Fig. 1). This area with an average water depth of $20 \mathrm{~m}$ is located south east of the island Helgoland. It is one of the few depositional areas in the North Sea (Hebbeln et al., 2003). Sediment deposition is forced by a small scale eddy, which is driven by long-shore coastal currents, the discharge of the rivers Elbe and Weser and tidal dynamics (Hertweck, 1983).

Table 1

Location of sampling sites, month/year of sampling, as well as benthic fluxes and sediment composition derived for these locations.

\begin{tabular}{|c|c|c|c|c|c|c|c|c|c|}
\hline Station/Acronym & Latitude & Longitude & Month Year & Sed. type (Figge) & $\varnothing$ & $b S i$ & $F_{\mathrm{s}}$ & $F_{\mathrm{pw}}$ & $F_{(\mathrm{c} 1 / \mathrm{c} 2)}$ \\
\hline \multicolumn{10}{|c|}{ A) In situ incubations and time series stations } \\
\hline He386-1/TS1 & $54^{\circ} 06^{\prime} 01.8^{\prime \prime}$ & $8^{\circ} 19^{\prime} 04.1^{\prime \prime}$ & August 2012 & $\mathrm{~m}$ & 0.8 & 3.7 & - & - & $3.6 / 5.5$ \\
\hline He395-52/TS1 & $54^{\circ} 06^{\prime} 02.9^{\prime \prime}$ & $8^{\circ} 19^{\prime} 10.9^{\prime \prime}$ & March 2013 & $\mathrm{~m}$ & 0.8 & 3.6 & 1.6 & - & - \\
\hline He383-46/TS2 & $54^{\circ} 04^{\prime} 09.5^{\prime \prime}$ & $8^{\circ} 01^{\prime} 07.7^{\prime \prime}$ & June 2012 & $\mathrm{fS}_{\text {high }}$ & 0.7 & 1.7 & 5 & - & $5.5 /-$ \\
\hline He395-38/TS2 & $54^{\circ} 04^{\prime} 13.2^{\prime \prime}$ & $8^{\circ} 01^{\prime} 05.4^{\prime \prime}$ & March 2013 & $\mathrm{fs}_{\text {high }}$ & 0.6 & 1.4 & - & - & $1.1 /-$ \\
\hline He412-27/TS2 & $54^{\circ} 03^{\prime} 45.0^{\prime \prime}$ & $8^{\circ} 01^{\prime} 00.6^{\prime \prime}$ & November 2013 & $\mathrm{fs}_{\text {high }}$ & 0.6 & 2.2 & 2.4 & - & $4.0 / 3.3$ \\
\hline He417-38/TS2 & $54^{\circ} 03^{\prime} 49.3^{\prime \prime}$ & $8^{\circ} 00^{\prime} 56.5^{\prime \prime}$ & March 2014 & $\mathrm{fs}_{\text {high }}$ & 0.9 & 2.4 & - & - & $0.3 / 0.4$ \\
\hline He386-33/TS3 & $54^{\circ} 11^{\prime} 04.2^{\prime \prime}$ & $8^{\circ} 15^{\prime} 09.0^{\prime \prime}$ & August 2012 & $\mathrm{fs}_{\text {low }}$ & 0.5 & 1.1 & 5.5 & - & $8.3 /-$ \\
\hline He395-62/TS3 & $54^{\circ} 11^{\prime} 06.7^{\prime \prime}$ & $8^{\circ} 15^{\prime} 09.7^{\prime \prime}$ & March 2013 & $\mathrm{fS}_{\text {low }}$ & 0.4 & 1.5 & 0.8 & - & - \\
\hline He412-38/TS3 & $54^{\circ} 11^{\prime} 04.8^{\prime \prime}$ & $8^{\circ} 15^{\prime} 09.0^{\prime \prime}$ & November 2013 & $\mathrm{fs}_{\text {low }}$ & 0.6 & 1.3 & 3.6 & 0.6 & $2.5 / 2.0$ \\
\hline He417-54/ TS3 & $54^{\circ} 11^{\prime} 02.4^{\prime \prime}$ & $8^{\circ} 15^{\prime} 03.6^{\prime \prime}$ & March 2014 & $\mathrm{fs}_{\text {low }}$ & 0.5 & 0.8 & - & - & $1.1 /-$ \\
\hline Не395-56/CS & $54^{\circ} 10^{\prime} 02.4^{\prime \prime}$ & $8^{\circ} 01^{\prime} 54.0^{\prime \prime}$ & March 2013 & cs & 0.4 & 0.6 & - & 0.1 & $1.0 /-$ \\
\hline \multicolumn{10}{|c|}{ B) Ex situ incubations and/or pore water studies } \\
\hline He386-15/M2 & $54^{\circ} 06^{\prime} 46.1^{\prime \prime}$ & $8^{\circ} 06^{\prime} 06.1^{\prime \prime}$ & August 2012 & $\mathrm{fs}_{\text {high }}$ & 0.6 & 1.7 & 4.5 & 0.8 & - \\
\hline He386-21/M5 & $54^{\circ} 04^{\prime} 00.1^{\prime \prime}$ & $7^{\circ} 57^{\prime} 57.6^{\prime \prime}$ & August 2012 & $\mathrm{fs}_{\text {high }}$ & 0.6 & 1.1 & - & 0.4 & - \\
\hline Не386-23/M6 & $54^{\circ} 05^{\prime} 03.5^{\prime \prime}$ & $7^{\circ} 57^{\prime} 56.9^{\prime \prime}$ & August 2012 & $\mathrm{fs}_{\text {high }}$ & 0.7 & 2.1 & 4.6 & 1.1 & - \\
\hline He386-4/M17 & $54^{\circ} 05^{\prime} 39.1^{\prime \prime}$ & $8^{\circ} 19^{\prime} 07.3^{\prime \prime}$ & August 2012 & $\mathrm{fs}_{\text {high }}$ & 0.7 & 2.7 & - & - & - \\
\hline He386-11/M19 & $54^{\circ} 07^{\prime} 45.1^{\prime \prime}$ & $8^{\circ} 01^{\prime} 16.7^{\prime \prime}$ & August 2012 & $\mathrm{fs}_{\text {high }}$ & 0.7 & 1.5 & - & - & - \\
\hline He386-20/M20 & $54^{\circ} 04^{\prime} 10.9^{\prime \prime}$ & $8^{\circ} 01^{\prime} 06.6^{\prime \prime}$ & August 2012 & $\mathrm{fs}_{\text {high }}$ & 0.6 & 1.8 & - & - & - \\
\hline Не386-17/M3 & $54^{\circ} 04^{\prime} 57.7^{\prime \prime}$ & $8^{\circ} 11^{\prime} 35.9^{\prime \prime}$ & August 2012 & $\mathrm{fs}_{\text {low }}$ & 0.5 & 1.4 & 2.5 & 0.9 & - \\
\hline He386-27/M7 & $54^{\circ} 10^{\prime} 01.9^{\prime \prime}$ & $8^{\circ} 15^{\prime} 34.9^{\prime \prime}$ & August 2012 & $\mathrm{fs}_{\text {low }}$ & 0.6 & 1.4 & 3 & 0.9 & - \\
\hline He386-29/M8 & $54^{\circ} 12^{\prime} 16.2^{\prime \prime}$ & $8^{\circ} 15^{\prime} 51.1^{\prime \prime}$ & August 2012 & $\mathrm{fs}_{\text {low }}$ & 0.4 & 0.6 & 1.5 & - & - \\
\hline Не386-42/M9 & $54^{\circ} 12^{\prime} 37.1^{\prime \prime}$ & $8^{\circ} 19^{\prime} 41.9^{\prime \prime}$ & August 2012 & $\mathrm{fs}_{\text {low }}$ & 0.5 & 0.9 & - & 0.5 & - \\
\hline Нe386-46/M11 & $54^{\circ} 10^{\prime} 39.7^{\prime \prime}$ & $8^{\circ} 19^{\prime} 43.7^{\prime \prime}$ & August 2012 & $\mathrm{fs}_{\text {low }}$ & 0.4 & 0.9 & 1.2 & 0.3 & - \\
\hline Нe386-47/M12 & $54^{\circ} 08^{\prime} 33.0^{\prime \prime}$ & $8^{\circ} 15^{\prime} 40.3^{\prime \prime}$ & August 2012 & $\mathrm{fs}_{\text {low }}$ & 0.6 & 2 & 1.2 & - & - \\
\hline Нe386-8/M1 & $54^{\circ} 05^{\prime} 15.7^{\prime \prime}$ & $8^{\circ} 20^{\prime} 57.1^{\prime \prime}$ & August 2012 & CS & 0.4 & 0.2 & 2.3 & - & - \\
\hline Нe386-19/M4 & $54^{\circ} 04^{\prime} 59.9^{\prime \prime}$ & $8^{\circ} 08^{\prime} 58.9^{\prime \prime}$ & August 2012 & Cs & 0.6 & 2.2 & 10.1 & 0.8 & - \\
\hline Нe386-45/M10 & $54^{\circ} 09^{\prime} 59.4^{\prime \prime}$ & $8^{\circ} 10^{\prime} 23.9^{\prime \prime}$ & August 2012 & cs & 0.4 & 0.4 & - & 0.4 & - \\
\hline Нe386-56/M13 & $54^{\circ} 01^{\prime} 36.0^{\prime \prime}$ & $8^{\circ} 17^{\prime} 31.2^{\prime \prime}$ & August 2012 & cs & 0.4 & 0.4 & 6.3 & - & - \\
\hline Не386-57/M14 & $54^{\circ} 01^{\prime} 16.8^{\prime \prime}$ & $8^{\circ} 07^{\prime} 36.0^{\prime \prime}$ & August 2012 & cs & - & 0.3 & 4.9 & - & - \\
\hline Нe386-58/M15 & $54^{\circ} 01^{\prime} 27.6^{\prime \prime}$ & $8^{\circ} 10^{\prime} 33.6^{\prime \prime}$ & August 2012 & Cs & 0.4 & 0.4 & 4.4 & - & - \\
\hline He386-59/M16 & $54^{\circ} 01^{\prime} 31.2^{\prime \prime}$ & $8^{\circ} 17^{\prime} 27.6^{\prime \prime}$ & August 2012 & cs & 0.5 & 0.2 & 1.7 & - & - \\
\hline He386-5/M18 & $54^{\circ} 05^{\prime} 6.0^{\prime \prime}$ & $8^{\circ} 19^{\prime} 13.1^{\prime \prime}$ & August 2012 & - & 0.8 & 0.5 & - & - & - \\
\hline
\end{tabular}

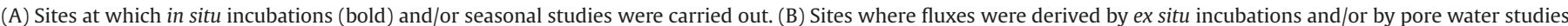

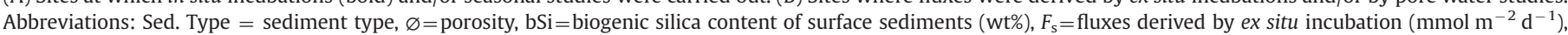

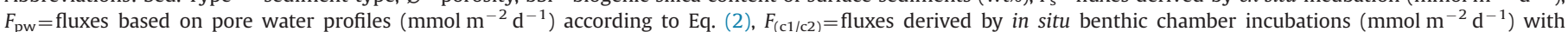
$\mathrm{c} 1=$ chamber 1 and $\mathrm{c} 2=$ chamber 2 and $(-)=$ no data available. 


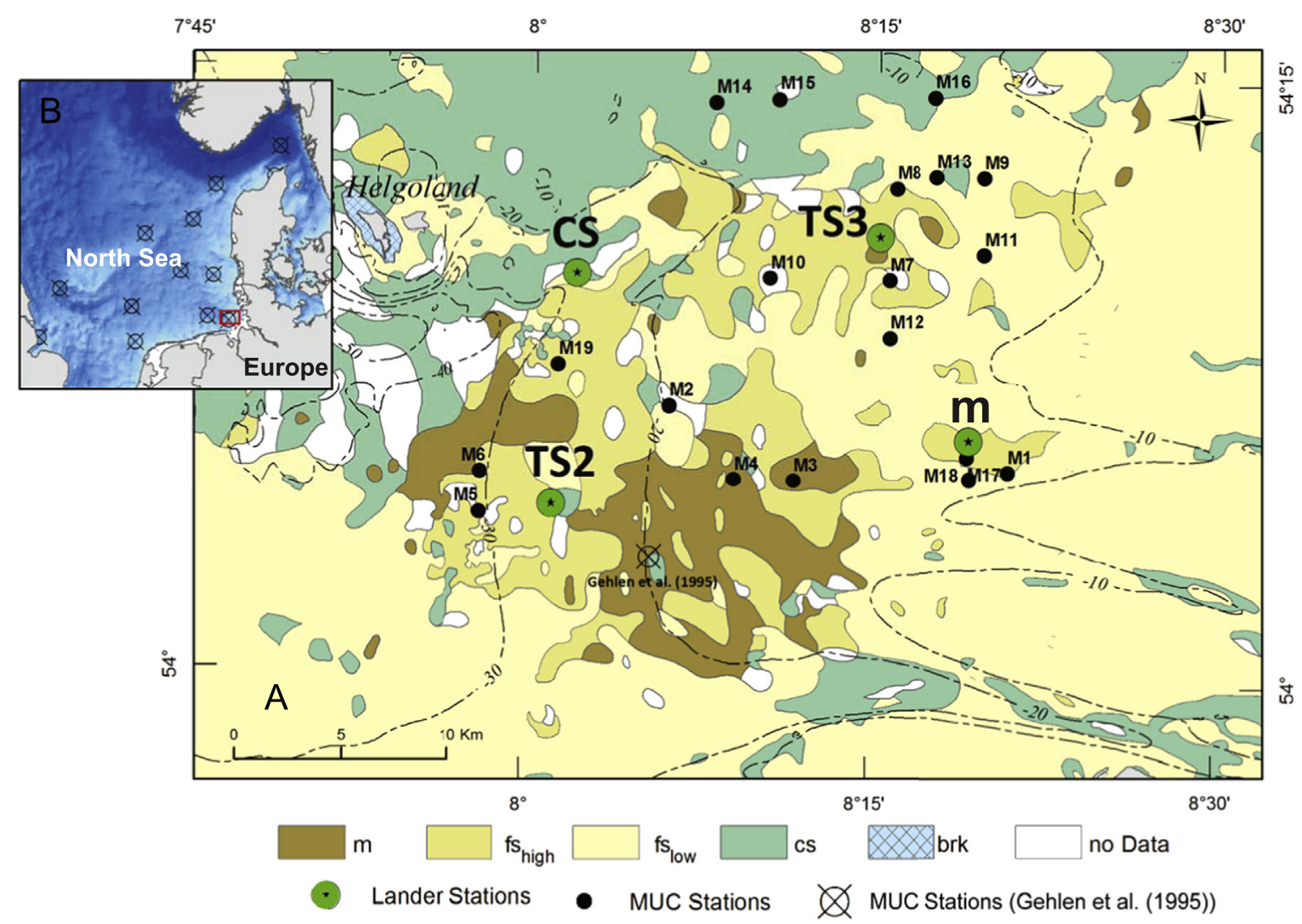

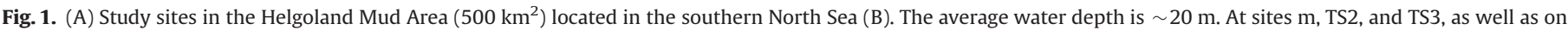

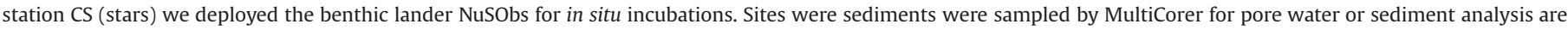

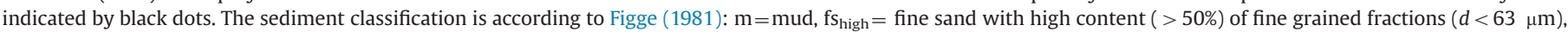

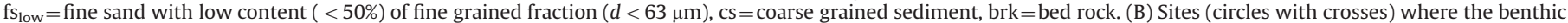
silica cycle was investigated by ex situ analysis by Gehlen et al. (1995).

Within the Helgoland Mud Area about $30 \mathrm{~m}$ of Holocene sediments have filled a morphological depression (Von Haugwitz et al., 1988). The surface sediments consist in the west of clayey silt and become more sandy towards the east (Hertweck, 1983). Sediment records and paleo-environmental reconstructions showed a drastic change in sedimentation around the year 1250, when sedimentation rates changed from $>13$ to $1.6 \mathrm{~mm} \mathrm{yr}^{-1}$ (Hebbeln et al., 2003). Based on ${ }^{210} \mathrm{~Pb}$ dating, present day average sedimentation rates of $7.7 \mathrm{~mm} \mathrm{yr}^{-1} \quad\left(\mathrm{~min}=2 \mathrm{~mm} \mathrm{yr}^{-1}\right.$, $\max =18 \mathrm{~mm} \mathrm{yr}^{-1}$ ) were estimated by Dominik et al. (1978) and $2.6 \mathrm{~mm} \mathrm{yr}^{-1}$ were estimated by Hebbeln et al. (2003).

In the southern German Bight phytoplankton blooms are regulated by the availability of light and nutrients in the water column (Beusekom and Diel-Christiansen, 2009). During winter the water column is enriched in nutrients but primary production is limited due to the low irradiation of light. During spring, phytoplankton blooms start to grow exponentially as soon as light radiation reaches a critical level (Sverdrup, 1953; Gieskes and Kraay, 1977). Within the German Bight spring phytoplankton blooms start to grow during the second half of April and occur in two different stages. The first spring bloom is dominated by diatoms and is in general limited by the availability of silicic acid in the water column (Beusekom and Diel-Christiansen, 2009). The second spring bloom is dominated by flagellates and its size is regulated by the amount of nitrogen and phosphorus nutrients which are left in the water column after the first diatom bloom (Gieskes and van Bennekom, 1973; Radach et al., 1990; Joint and Pomroy, 1993). During summer most nutrients are delivered into the coastal zone due to the mineralization of organic matter and continental freshwater inputs (Brockmann and Eberlein, 1986;
Beusekom and Diel-Christiansen, 2009). In general, one or two additional diatom blooms occur which are mostly followed up by non-diatom (flagellate) blooms (Radach et al., 1990). In August phytoplankton production reaches another maximum, which is followed by a decrease to lowest production in October-November (Radach et al., 1990; Beusekom and Diel-Christiansen, 1994).

\subsection{In situ and ex situ benthic flux measurements}

Fig. 1 shows the study area, the sediment types and the sites at which the benthic lander NuSObs (Nutrient and Suspension Observatory) was deployed and sediment cores were sampled. Different sediment types, from muddy to sandy sediments were investigated. To consider seasonal variations, two time series sites (TS2, TS3) were revisited in the years 2012, 2013 and 2014 during various seasons with the research vessel $R V$ Heincke (Fig. 1, Table 1).

For in situ flux studies we developed and applied the benthic lander system NuSObs. The lander was equipped with two "Mississippi" type chambers each enclosing a sediment area of $400 \mathrm{~cm}^{2}$ (Witte and Pfannkuche, 2000; Tengberg et al., 2004). After the deployment of the lander, both chambers were moved by a motor into the sediment without disturbing the sediments surface. Each chamber was equipped with a syringe sampler ( 7 glass syringes, with a volume of $50 \mathrm{ml}$ ), an oxygen Optode (Aanderaa ${ }^{\mathrm{TM}}$, Optode 4330 ), as well as a $\mathrm{pH}$ sensor (AMT/OEM ${ }^{\mathrm{TM}}$ ). The syringe sampler was pre-programmed to obtain water samples from the chamber every $2-3 \mathrm{~h}$. By this mean, a time series of silicic acid concentrations within the chamber was obtained. Incubations were in general carried out over a time interval of $12-24 \mathrm{~h}$. 

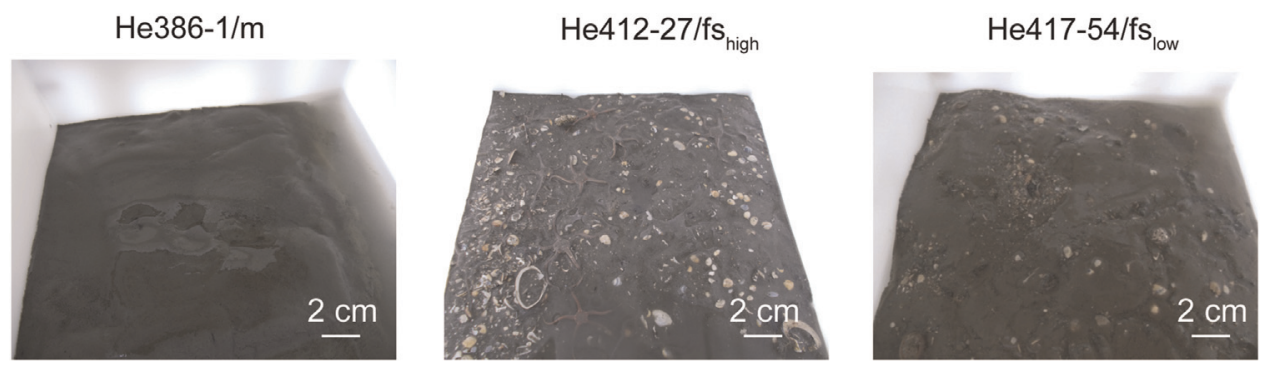

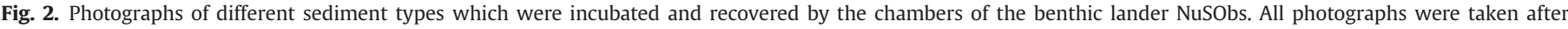
NuSObs was recovered and the bottom water was released from the benthic chambers.

During the retrieval of the lander the incubated sediment and the bottom water was recovered by closing a lid underneath the chamber (Fig. 2). In addition to the detection of the penetration of the chamber into the sediment this allows to quantify the volume of the incubated water which is a prerequisite for a precise flux calculation. The sediment was sampled for sedimentological and geochemical analysis.

The efflux of silicic acid from the sediment was calculated by linear regression of the concentration of silicic acid versus time applying the statistical software $\mathrm{R}$. The slope of the regression line was multiplied with the volume of the water incubated in the chamber and divided by the area of the chamber to calculate the flux of silicic acid across the sediment water interface.

For ex situ, shipboard flux measurements sediment cores were incubated at in situ temperatures in the cooling room of the research vessel. The incubation and sampling started immediately after recovery of the core. For ex situ flux studies, the overlying water of the sediment core was sampled every one to two hours. The maximum incubation time was $9 \mathrm{~h}$. The water samples were filtered with a cellulose acetate filter (pore size $=0.45 \mu \mathrm{m}$ ) and subsequently stored at $4{ }^{\circ} \mathrm{C}$ in a refrigerator. Within a few days the $\mathrm{Si}(\mathrm{OH})_{4}$ concentration was analyzed by the segmented flow analyzer (Seal' ${ }^{\mathrm{TM}}$ Analytical Autoanalyzer). The accuracy of the analysis is $\pm 2 \mu \mathrm{mol} \mathrm{l}^{-1}$. As for the chambers, the silicic acid efflux was calculated from the increase of the $\mathrm{Si}(\mathrm{OH})_{4}$ concentration versus time.

\subsection{Sediment and pore water sampling}

Sediments were sampled with a multiple corer equipped with 8 cores (inner diameter of $9.5 \mathrm{~cm}$ ) made of acrylic glass (Barnett et al., 1984). Generally, the cores recovered the upper $10-30 \mathrm{~cm}$ of the surface sediment. Subsequently to the recovery, the cores were sampled on ship board in a temperature regulated room adjusted to ambient bottom water temperature. The overlying water was sampled by a syringe and filtered with a cellulose acetate filter $(0.45 \mu \mathrm{m}$ pore size). Pore water samples were collected with Rhizons with a vertical resolution of one to two centimeters within the sediment (Seeberg-Elverfeldt et al., 2005). The water and pore water samples were filtered and stored at $4{ }^{\circ} \mathrm{C}$ in a refrigerator. The concentration of silicic acid was analyzed by a Segmented Flow Analyzer (Seal ${ }^{\mathrm{TM}}$ Analytical Autoanalyzer) within a few days.

Sediment samples were taken from the same depths as the pore water samples for measurements of porosity, biogenic silica content, as well as grain sizes. Grain sizes were determined with a coulter counter particle laser (diffraction) meter. The sediment was categorized according to Figge (1981) into mud (m), fine sand $\left(\mathrm{fs}_{\text {high }}, \mathrm{fs}_{\text {low }}\right)$ and sediments which are coarser than fine sand (cs). This sediment classification especially considers differences of fine grained particles $(d<63 \mu \mathrm{m})$, which is for benthos-biological processes of importance. In this context mud (m) is classified as sediment containing more than $80 \%$ of fine grained material $(<63 \mu \mathrm{m}) . \mathrm{Fs}_{\text {high }}$ is fine sand containing more than $50 \%$ and $\mathrm{fs}_{\text {low }}$ is fine sand containing less than $50 \%$ of fine grained material $(d<63 \mu \mathrm{m})$ (Table 1$)$. Porosity was calculated assuming a sediment density of $2.65 \mathrm{~g} \mathrm{~cm}^{-3}$ (Breitzke, 2006) and determining the water content by the weight loss after freeze drying. The biogenic silica content of the sediment was determined by leaching the sediment sample according to Müller and Schneider (1993).

To assess the influence of macrofauna species on the sedimentary environment via e.g . actively reworking and irrigating the sediment or transport oxygen and organic matter deeper into the sediment, macrofauna species were sampled at time series site TS2 in 2013 and 2014 from sediment cores. The upper $20-30 \mathrm{~cm}$ of the sediment were sliced in $5 \mathrm{~cm}$ segments $(0-5,5-10,10-15,15-$ $20,20-25 \mathrm{~cm})$ and sieved on board of the research vessel over $500 \mu \mathrm{m}$ mesh size which retained nearly all individuals of those taxa generally regarded as members of the macrofauna. Samples were fixed in $4 \%$ buffered formaldehyde-seawater solution. In the lab, samples were stained with Bengal rose and all macrofauna was sorted, identified to the lowest possible taxonomic level and counted. Mean species abundance was standardized to an area of $1 \mathrm{~m}^{2}$. Each species was classified into functional feeding groups (surface deposit feeders, subsurface deposit feeders, suspension feeders, omnivores, predators, interface feeders) and functional types (surficial modifier, biodiffuser, upward conveyor, upwarddownward conveyor) based on available literature (e.g. Fauchald and Jumars, 1979; Queirós et al., 2013).

\subsection{Computation of benthic fluxes and recycling efficiency}

Biogenic silica which reaches the sediment water interface is either dissolved and transported back into the water column in the form of silicic acid, or is being buried within the sediment. Consequently, the rain rate of biogenic silica $\left(\mathrm{bSi}_{\text {rain }}\right)$ reaching the seafloor is equal to the sum of the reflux of silicic acid $\left(\mathrm{Si}(\mathrm{OH})_{4}\right.$ efflux $)$ back into the water column and the mass accumulation ( $\mathrm{bSi}_{\mathrm{acc}}$ ) in the sediment (Schlüter et al., 1998; Ragueneau et al., 2009; Tréguer and De La Rocha, 2013):

$\mathrm{bSi}_{\text {rain }}=\mathrm{Si}(\mathrm{OH})_{4 \text { efflux }}+\mathrm{bSi}_{\mathrm{acc}}$

with

$\mathrm{bSi}_{\text {rain }}$ : total flux of biogenic silica reaching the seafloor $\left(\mathrm{mol} \mathrm{m} \mathrm{m}^{-2} \mathrm{yr}^{-1}\right)$,

$\mathrm{Si}(\mathrm{OH})_{4}$ efflux: efflux of silicic acid across the sediment water interface $\left(\mathrm{mol} \mathrm{m}^{-2} \mathrm{yr}^{-1}\right)$,

$\mathrm{bSi}_{\mathrm{acc}}$ : accumulation rate of biogenic silica within the sediment $\left(\mathrm{mol} \mathrm{m}-2 \mathrm{yr}^{-1}\right)$

and

$\mathrm{bSi}_{\mathrm{acc}}=(1-\varnothing) * w_{*} S_{*} \mathrm{bSi}$

$\varnothing$ : porosity $(-)$,

$w$ : dry sediment density $\left(\mathrm{kg} \mathrm{m}^{-3}\right)$, 
$s$ : sedimentation rate $\left(\mathrm{m} \mathrm{yr}^{-1}\right)$,

bSi: weighted percentage of biogenic silica (wt\%).

For Eq. (1) the accumulated biogenic silicia ( $\mathrm{bSi}_{\mathrm{acc}}$ ) within the sediment (Eq. (2)) is converted from $\mathrm{kg} \mathrm{m}^{-2} \mathrm{yr}^{-1}$ into $\mathrm{mol} \mathrm{m} \mathrm{mr}^{-1}$. The ratio between the silicic acid flux $\left(\mathrm{Si}(\mathrm{OH})_{4}\right.$ efflux $)$ and the total bSi rain rate $\left(\mathrm{bSi}_{\text {rain }}\right)$ is an indicator for the efficiency of a sediment to recycle biogenic silica and transport the nutrient silicic acid back into the water column. For the calculation of mass accumulation rates of biogenic silica within the sediment, average porosities and average biogenic opal concentrations for respective sediment types were chosen. Furthermore we selected a sedimentation rate of $0.0026 \mathrm{~m} \mathrm{yr}^{-1}$ (Hebbeln et al., 2003) and a bulk dry sediment density of $2650 \mathrm{~kg} \mathrm{~m}^{-3}$. The efflux of silicic acid $\left(\mathrm{Si}(\mathrm{OH})_{4}\right.$ flux $)$ from the sediment to the water column was directly measured by in situ and ex situ incubations.

Based on pore water profiles, we calculated the diffusive flux of solutes along the sediment-water interface. Several $\mathrm{Si}(\mathrm{OH})_{4}$ pore water profiles are characterized by an exponential curvature close to the sediment water interface and a constant, asymptotic concentration at sediment depths (Vanderborght et al., 1977; Raaphorst et al., 1990; Gehlen et al., 1995). For this type or pore water profiles, different types of models or fitting function were developed for the calculation of fluxes across the sediment water interface (Hurd, 1973; Gehlen et al., 1995). We applied an
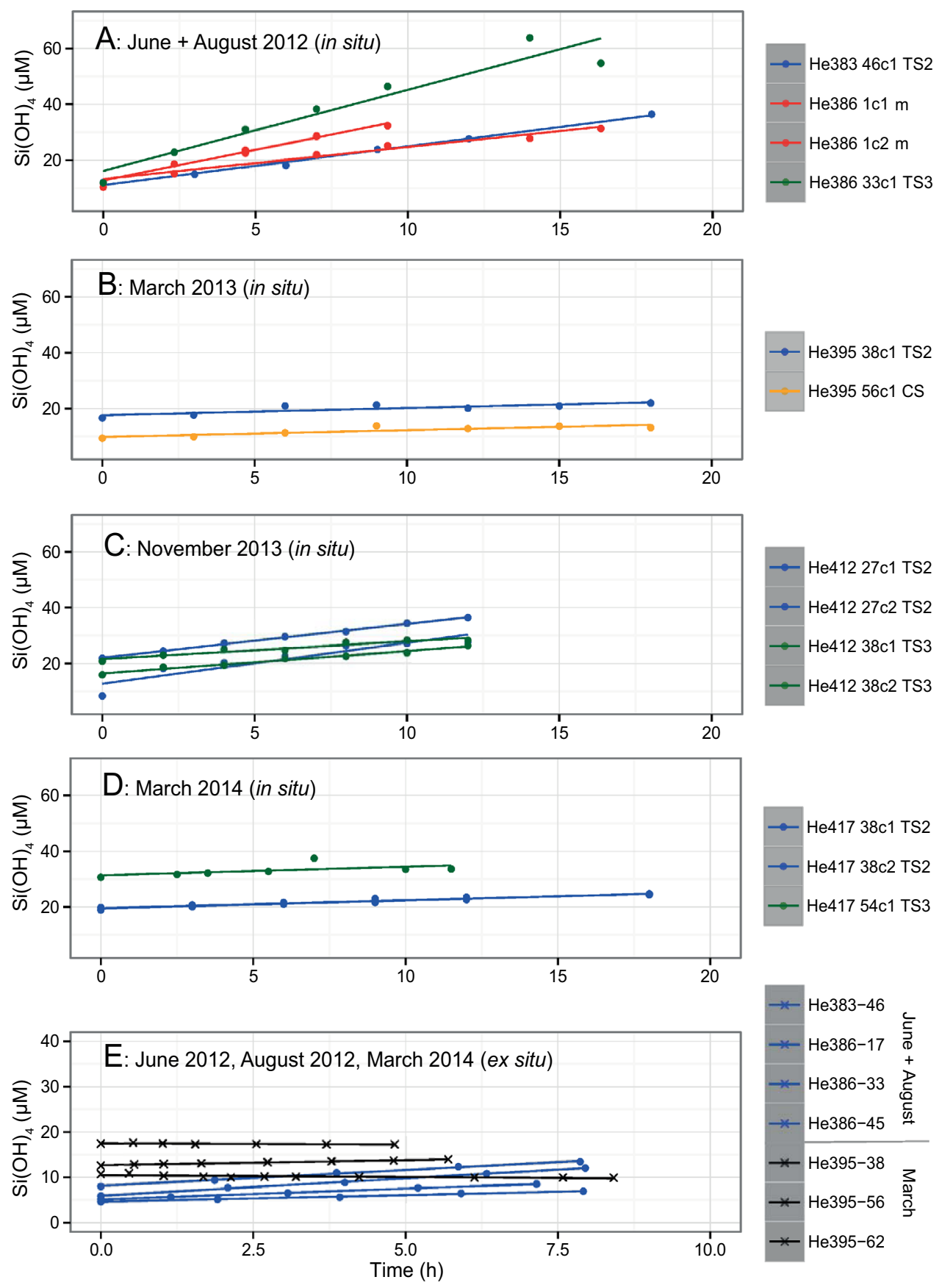

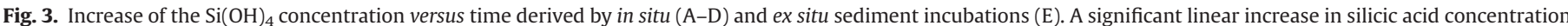

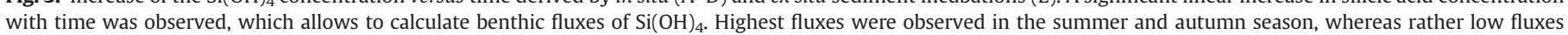

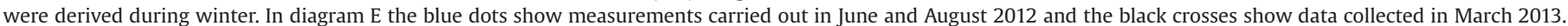
(For interpretation of the references to color in this figure legend, the reader is referred to the web version of this article.) 
A
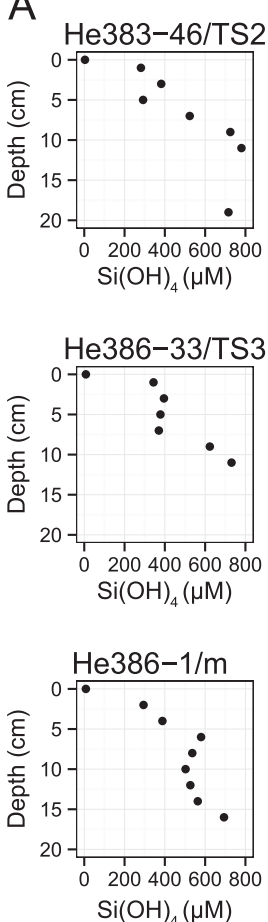

B
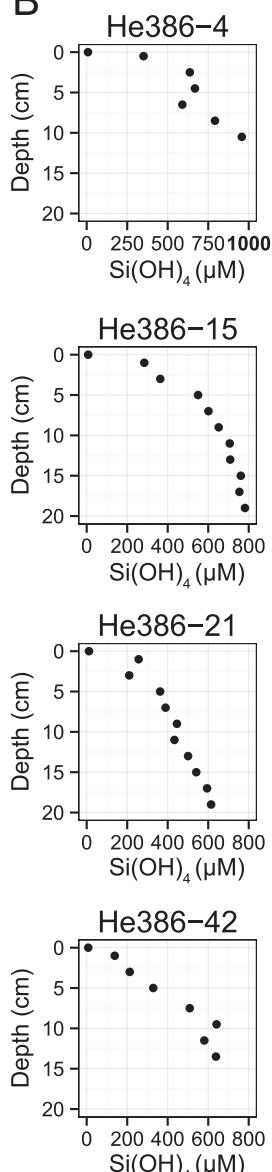
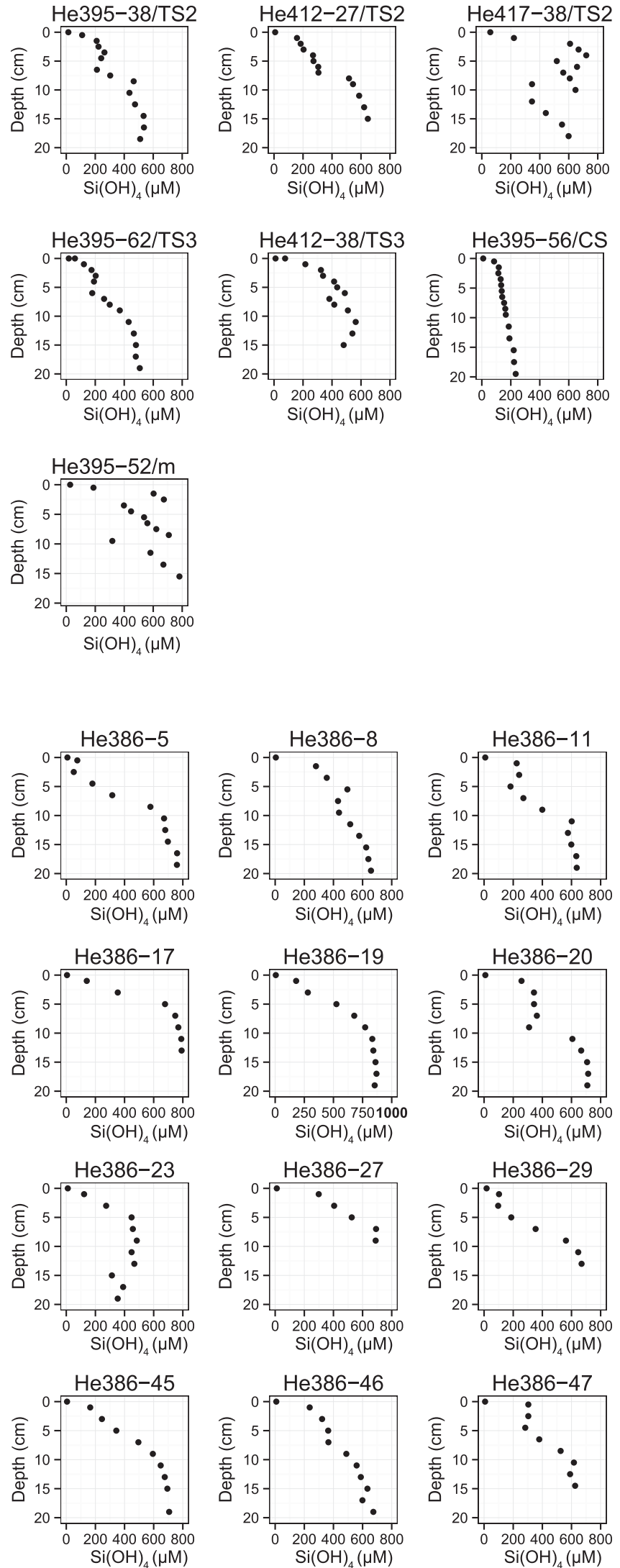

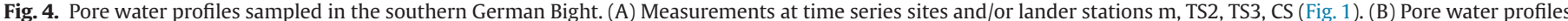

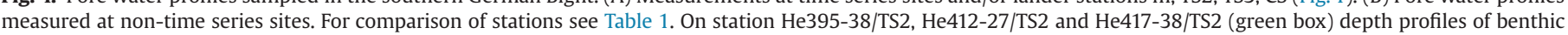

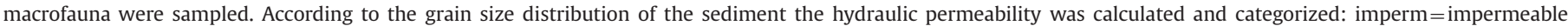
sediments, semi-perm $=$ semipereable, perm $=$ permeable. 
exponential decay equation (Eq. (3)) fitted to the measured silicic acid profile (Gehlen et al., 1995; van Raaphorst et al., 1990):

$F_{0}=\varnothing D_{\text {eff }} \delta^{-1}\left(S_{0}-S_{\mathrm{b}}\right)$

$\delta=\left(D_{\text {eff }} / K_{\mathrm{Si}}\right)^{1 / 2}$

with:

$F_{0}$ : diffusive flux of silicic acid across the sediment water interface $\left(\mathrm{mmol} \mathrm{m}^{-2} \mathrm{~d}^{-1}\right)$,

$D_{\text {eff: }}$ molecular diffusion coefficient corrected for temperature and tortuosity $\left(\mathrm{m}^{2} \mathrm{~s}^{-1}\right)$ (Boudreau, 1997),

$\delta$ : depth constant $(\mathrm{m})$,

$\mathrm{Si}_{0}$ : bottom water concentration of silicic acid $\left(\mathrm{mmol} \mathrm{m}^{-3}\right)$,

$\mathrm{Si}_{\mathrm{b}}$ : asymptotic concentration of silicic acid at sediment depth $\left(\mathrm{mmol} \mathrm{m}^{-3}\right)$,

$K_{\mathrm{Si}}$ : first order reaction rate $\left(\mathrm{s}^{-1}\right)$.

The exponential decay equation (Eq. (3)) was fitted to the measured silicic acid profile by adjusting the depth constant $\delta$. The best fit was obtained by minimizing the sum of the least squares of the residuals (difference between measured and calculated concentration) applying the statistical software package $\mathrm{R}$. The depth constant $\delta$ reflects the ratio between the transport by molecular diffusion ( $\left.D_{\text {eff }}\right)$ and the reaction rate $\left(k_{\mathrm{Si}}\right)$ of bSi. A detailed description of Eq. (3) is provided by Gehlen et al. (1995).

\section{Results}

\subsection{In situ benthic chamber- and ex situ shipboard flux measurements}

The time series sites (TS2, TS3, Fig. 1) investigated by in situ incubations cover two different types of fine sand (fs) deposits ( $\mathrm{fs}_{\text {high }}$ and $\mathrm{fs}_{\text {low }}$ ). During the in situ incubations (about $12-24 \mathrm{~h}$ at the seafloor), the increase of the $\mathrm{Si}(\mathrm{OH})_{4}$ concentration versus time within the benthic chamber is nearly linear (Fig. 3). The slope of the increase of $\mathrm{Si}(\mathrm{OH})_{4}$ over time indicates the efflux of silicic acid. This efflux is caused by dissolution of particulate biogenic silica and by transport processes like molecular diffusion or biological mediated transport (e.g. bioirrigation). The benthic fluxes of $\mathrm{Si}(\mathrm{OH})_{4}$ through the sediment water interface derived by in situ as well as ex situ incubations are summarized in Table 1.

On time series site TS2 (Table 1, Fig. 1) the efflux of silicic acid followed a seasonal cycle with highest effluxes in June 2012 (5.5 mmol m-2 $\mathrm{d}^{-1}$ ), low effluxes in March 2013 $\left(1.1 \mathrm{mmol} \mathrm{m}^{-} \mathrm{d}^{-1}\right)$, higher effluxes in November 2013 (3.3-4.0 mmol m $\mathrm{m}^{-2} \mathrm{~d}^{-1}$ ) and very low effluxes in March 2014 (0.3-0.4 mmol m- $\left.\mathrm{d}^{-1}\right)$. Ex situ incubations were carried out on time series station TS2 in June 2012, March 2013 and November 2013. In June 2012 and November 2013 ex situ determined silicic acid effluxes were slightly lower as compared with the in situ determined flux rates. In March 2013 we did not observe a significant change in silicic acid concentration with time in the ex situ incubated core.

On time series site TS3 (Table 1, Fig. 1), the silicic acid effluxes measured in situ followed a temporal pattern with highest flux rates in August $2012\left(8.3 \mathrm{mmol} \mathrm{m}^{-2} \mathrm{~d}^{-1}\right)$, low flux rates in March $2014\left(1.1 \mathrm{mmol} \mathrm{m}^{-2} \mathrm{~d}^{-1}\right)$, as well as intermediate flux rates in November $2013\left(2.0-2.5 \mathrm{mmol} \mathrm{m}^{-2} \mathrm{~d}^{-1}\right)$. The sediment type did not vary in between the different seasons and consisted of a fine sand ( $\mathrm{fs}_{\text {low }}$ ) with lower porosities (0.4-0.6) and lower bSi contents (0.8-1.5 wt\%), when compared to station TS2. In situ incubations at site He395-56/CS (CS: coarse sediment) by the NuSObs lander were carried out in March 2013. Silicic acid effluxes were low $\left(1.0 \mathrm{mmol} \mathrm{m}^{-2} \mathrm{~d}^{-1}\right)$. The coarse grained sediments (cs) had a low
bSi content of 0.6 wt\%. On site He386-1/m we carried out in situ incubations with the benthic lander NuSObs in August 2012. Fluxes ranged from 3.6 to $5.5 \mathrm{mmol} \mathrm{m} \mathrm{m}^{-2} \mathrm{~d}^{-1}$. The sediment type (mud) had a relatively high bSi contents of $3.7 \mathrm{wt} \%$.

The ex situ flux measurements revealed a similar efflux of silicic acid (Fig. 3e), as in situ flux measurements (Fig. 3a-d). Highest ex situ measured fluxes were observed in June and August (1.2-10.1 mmol m $\mathrm{m}^{-2} \mathrm{~d}^{-1}$, average efflux of: $3.9 \mathrm{mmol} \mathrm{m}^{-2} \mathrm{~d}^{-1}$ ), moderate fluxes in November $\left(2.4-3.6 \mathrm{mmol} \mathrm{m}^{-2} \mathrm{~d}^{-1}\right)$ and lowest fluxes in March $\left(0.8-1.6 \mathrm{mmol} \mathrm{m}{ }^{-2} \mathrm{~d}^{-1}\right)$.

\subsection{Pore water profiles of Si(OH $)_{4}$ and biogenic silica contents of surface sediments}

Pore water profiles provide information about reaction and transport processes (e.g. bioirrigation) by interpretation or numerical modelling of the curvature of concentration versus depth profiles (Boudreau, 1997). Examples about pore water profiles measured for sediments of the Helgoland Mud Area are shown in Fig. 4.

Considering the shape of the pore water profiles a steady increase of silicic acid concentrations with sediment depth close to the sediment water interface and an asymptotic $\mathrm{Si}(\mathrm{OH})_{4}$ concentration at depth was observed on several stations. Such pore water profiles (Fig. 4) are typical for a diffusive transport of silicic acid within the sediment (Lerman, 1978; Berner, 1980). To calculate benthic silicic acid fluxes from pore water profiles, we only considered these profiles. The calculated diffusive fluxes are in the range of $0.1-1.1 \mathrm{mmol} \mathrm{m}^{-2} \mathrm{~d}^{-1}$ (Table 1). In August the median diffusive flux of $\mathrm{Si}(\mathrm{OH})_{4}$ is $0.7 \mathrm{mmol} \mathrm{m}^{-2} \mathrm{~d}^{-1}$. One exceptional site was station HE396-56/CS with relatively low asymptotic pore water concentrations of $220 \mu \mathrm{mol} \mathrm{l}^{-1}$, being located on a coarse grained sediment type. Similar profiles were observed by other authors in coarse grained sediment types in the North Sea (e.g. Gehlen et al., 1995), which are typical for non-depositional environments.

In most of the remaining pore water profiles we observed a two layer pattern with varying silicic acid concentrations within the upper $3-9 \mathrm{~cm}$ of the sediment, followed by a nearly asymptotic pore water profile at depth. The shape of these pore water profiles is typical for advective transport processes in the upper sediment column and a diffusive transport below. Based on the measured grain size distribution, we computed the hydraulic permeability of the sediments (Puls, pers. comm.). The permeability of most surface sediments is below $10^{-12} \mathrm{~m}^{2}$ which we consider as impermeable sediments with respect to e.g. wave induced transport (Vanderborght et al., 1977; Huettel et al., 2014).

Biogenic silica contents (bSi) of surface sediments varied between $0.2 \mathrm{wt} \%$ and $3.7 \mathrm{wt} \%$ (Table 1). These values are in a similar range as observed for sediments in the North Atlantic and other coastal regions (DeMaster et al., 1983; Schlüter and Sauter, 2000; Berelson et al., 2003). Higher median bSi contents were related to sediment types with a higher fraction of fine grained material (Figge, 1981): $m=3.6 \mathrm{wt} \%, n=2 ; \mathrm{fs}_{\text {high }}=1.9 \mathrm{wt} \%, n=10 ; \mathrm{fs}_{\text {low }}$ $=1.2 \mathrm{wt} \%, n=10 ; \mathrm{cs}=0.6 \mathrm{wt} \%, n=8$.

\subsection{Vertical distribution of dominant macrofauna species}

Different functional types of benthic macrofauna were distinguished. Surficial modifiers (S) are organisms whose activities are restricted to the uppermost sediment layers $0-2 \mathrm{~cm}$. The activities of biodiffusors (B) result in a random transport of particles over small distances. Upward conveyors (UC) feed vertically within the sediment with their head located at depth, while downward conveyors (DC) are head-up oriented feeders which transport particles or solutes vertically from the sediment water interface to depth (Solan and Wigham, 2005). 
A

He395-38/TS2 (March 2013)

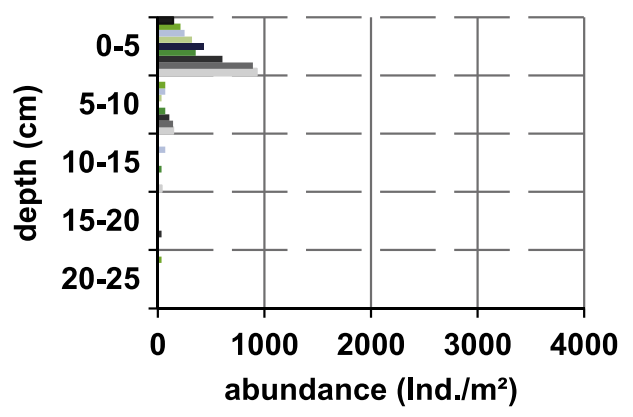

C

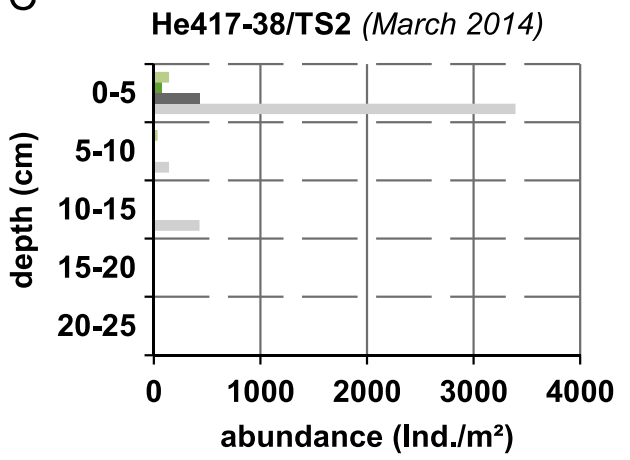

B

He412-27/TS2 (November 2013)

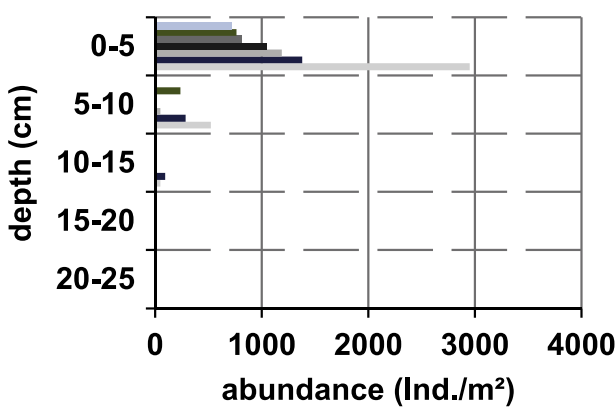

Spiophanes bombyx (UC/DC)

- Capitellidae juv. (UC)

Nephtys spp. (B)

- Scalibregma inflatum (B)

- Amphiura filiformis $(B)$

- Goniada maculata (B)

- Scolopus armiger (B)

- Ophiuridae juv. (S)

- Abra nitida (S)

- Pholoe baltica (S)

- Nucula nitidosa (S)

- Kurtiella bidentata (S)

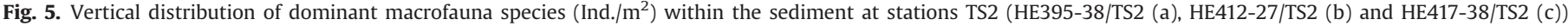
sampled in 2013 and 2014. Abbreviations: S=surficial modifier, B=biodiffuser, UC=upward conveyor, and UC/DC=upward-downward conveyor.

In general, highest species numbers and mean abundance (Ind./ $\mathrm{m}^{2}$ ) were found in the first $5 \mathrm{~cm}$ of the sediment. Lowest mean abundances occurred in March 2013, which increased in November 2013. Mean abundances in March 2014 were higher compared to March 2013 probably attributed to the warm winter (Fig. 5). The most abundant species for each station are shown in Appendix A. The community structure was dominated by surficial modifiers (Nucula nitidosa, Kurtiella bidentata), biodiffusers (Scoloplos armiger, Amphiura filiformis, Scalibregma inflatum) and upward/downward conveyors like Spiophanes bombyx and Capitellidae.

\section{Discussion}

Our in situ and ex situ benthic flux data derived for different seasons between 2012 and 2014 allow a comparison of methods applied for quantification of benthic fluxes, the identification of temporal variations, estimates about the preservation efficiency of bSi in sediments and calculation of spatial budgets about the reflux of $\mathrm{Si}(\mathrm{OH})_{4}$ into the bottom water.

\subsection{Comparison of techniques applied for benthic flux measurements}

Considering results derived by sediment incubations, fluxes determined ex situ were in general lower than fluxes measured in situ. On stations He395-38/TS2 and He395-56/CS no significant $\mathrm{Si}(\mathrm{OH})_{4}$ fluxes were measured in ex situ incubations, while a significant flux was observed by in situ incubations. On three sites (He383-46/TS2, He412-27/TS2, He386-33/TS3) in situ flux measurements showed approximately $10-30 \%$ higher flux rates than those derived by the ex situ incubations. These results are in accordance to studies by Hammond et al. (2004), who investigated benthic fluxes (e.g. $\mathrm{Si}(\mathrm{OH})_{4}, \mathrm{PO}_{4}$ or $\mathrm{NO}_{3}$ ) by ex situ and in situ incubations of sediments derived from water depths of 100-3300 m at the California margin. Compared with the in situ derived fluxes, Hammond et al. (2004) observed a systematical reduction of 15$30 \%$ in ex situ studies. Largest offsets between in situ and ex situ incubations were observed in shallow water sites, where most of the benthic fauna is present (Hammond et al., 2004). Differences in flux rates were caused by a reduction in irrigating activity of benthic fauna in recovered cores.

Advantages of in situ studies are the larger area incubated by a benthic chamber (area $400 \mathrm{~cm}^{2}$ ) when compared to e.g. multiple corer tubes (area $70 \mathrm{~cm}^{2}$ ). Therefore, the probability to assess the activity by macrofauna species, when compared to sediment cores is considerably higher. Furthermore artifacts which are related to changes in macrofaunal behavior may be less under in situ conditions, compared to shipboard incubations at which the benthic community was exposed to a stressful recovery process (Glud, 2008). Consequently, in situ benthic chamber incubations represent benthic fluxes, affected by biological mediated transport like bioirrigation, more accurate than ex situ incubations and are better suited for process oriented studies like quantification of bioirrigation by tracer injection. This underlines the advantage of in situ techniques in shallow water sediments, which are in general inhabited by abundant benthic macrofauna (Glud, 2008).

Compared with sediment incubations, the benthic fluxes calculated from pore water profiles are considerably lower. The pore water derived fluxes are by a factor of 7 lower than those measured in incubation experiments (ratio of lower fluxes for all stations: average $=6.5, \min =2.9, \max =15.6)$. Such a discrepancy was observed by Gehlen et al. (1995) in the Helgoland Bight and in the Skagerrak (Fig. 1B) as well and seems to be attributed to an enhanced transport by irrigating macrofauna, 
which is not considered in pore water calculations. Depth profiles of the abundance of benthic macrofauna (Fig. 5) suggest that the shape of the silicic acid pore water profile was affected by the functional type of macrofauna within different sediment layers. On station He395-38/TS2 and He417-27/TS2 distinct changes in the silicic acid pore water profile at a depth of 5$10 \mathrm{~cm}$ might be explained by the upward and downward conveyor (Fig. 5, UC/DC) Spiophanes bombyx or biodiffusors (Fig. 5B) such as Goniada maculata or A. filiformis which were observed within this sediment depth. Surficial modifiers (Fig. 5S) most likely did not affect the pore water composition, as their activity is restricted to the uppermost two centimeters of the sediment (Queirós et al., 2013). Surficial modifiers which were observed on station He417-38/TS2 down to sediment depths of $20 \mathrm{~cm}$ might be related to sampling artifacts, as benthic fauna can be forced into the sediment while being sampled with a multiple corer.

\subsection{Temporal variability of benthic fluxes}

For the southern North Sea, our in situ measurements on time series sites TS2 and TS3 revealed temporal variations of silicic acid effluxes of $5.5-8.3 \mathrm{mmol} \mathrm{m}^{-2} \mathrm{~d}^{-1}$ (June and August 2012), 2.0-4.0 mmol m${ }^{-2} \mathrm{~d}^{-1} \quad$ (November 2013) and $0.3-1.1 \mathrm{mmol} \mathrm{m}^{-2} \mathrm{~d}^{-1}$ (in March 2013 and 2014). Such variations could be caused by chemical processes related to solubility and kinetics, as well as biological mediated transport which could cause a considerable under saturation of $\mathrm{Si}(\mathrm{OH})_{4}$ in the sediment due to flushing by bottom water (Aller and Yingst, 1985; Marinelli, 1992).

In Fig. 6, bottom water temperatures, sediment types, as well as $\mathrm{Si}(\mathrm{OH})_{4}$ fluxes measured by in situ and ex situ incubations on time series/lander sites (Table 1A), are shown. We observe a linear relationship between the bottom water temperature $\left(T_{\mathrm{BW}}\right)$ and the in situ measured silicic acid fluxes of the time series stations TS2 and TS3 $\left(r^{2}=0.8084, n=10\right)$. Fluxes measured in July 2012 at site TS2 $\left(T_{\mathrm{BW}}=14^{\circ} \mathrm{C}\right)$ are about 5 times higher as those observed in March $2013\left(T_{\mathrm{BW}}=3{ }^{\circ} \mathrm{C}\right)$ and of similar magnitude than November 2013 , for $T_{\mathrm{BW}}=13^{\circ} \mathrm{C}$. A similar pattern was observed for site TS3. A correlation in between benthic silicic acid fluxes and the bottom water temperature was observed in other shallow water systems (e.g. the bay of Brest) as well (Ragueneau et al., 1994). The bottom water temperature has an effect on the molecular diffusion coefficient and might decrease flux rates by about 1.6 times for a temperature drop from $15{ }^{\circ} \mathrm{C}$ to $5{ }^{\circ} \mathrm{C}$ (e.g. Berner, 1980). Furthermore the solubility of a solid phase and the reaction rate is affected by the temperature. A temperature drop from $15^{\circ} \mathrm{C}$ to $5{ }^{\circ} \mathrm{C}$ would decrease the solubility of amorphous silica by about $20 \%$ and decrease the reaction rate by 3.5 (Wollast, 1974; Dixit et al., 2001; Rickert et al., 2002).

Furthermore, benthic macrofauna seems to play an important role in the effluxes of silicic acid, as indicated by ex situ incubations, in situ incubations and pore water flux calculations. Higher fluxes might be related to higher abundances of benthic macrofauna (e.g. upward/downward conveyors; Fig. 5; UC/DC) during summer and autumn. Such as bacteria, benthic macrofauna might contribute to enhanced bSi dissolution within the sediment by removing organic coatings from opal surfaces (Bidle and Azam, 1999; Chauvaud et al., 2000). Higher benthic silicic acid fluxes can further be related to the density of burrow or tube structures (Aller, 1982) and to the activity of burrow inhabitants (Marinelli, 1992). For the North Sea, benthic silicic acid fluxes can be enhanced by a factor of $1.1-3.4$ by bioirrigation, which was shown in ex situ incubations before (Gehlen et al., 1995).

\subsection{Recycling efficiency of silicic acid into the bottom water}

In shallow coastal waters like the southern German Bight (water depth of about $20-40 \mathrm{~m}$ ) a close coupling between pelagic and benthic processes is obvious, due to the short residence time of particles (e.g. aggregates or phyto- and zooplankton) in the water column. Therefore, the remineralisation and dissolution of particles in the water column during the transfer to the seafloor should be rather low, when compared with continental margins or the open ocean (e.g. DeMaster, 2002; Tréguer and De La Rocha, 2013).

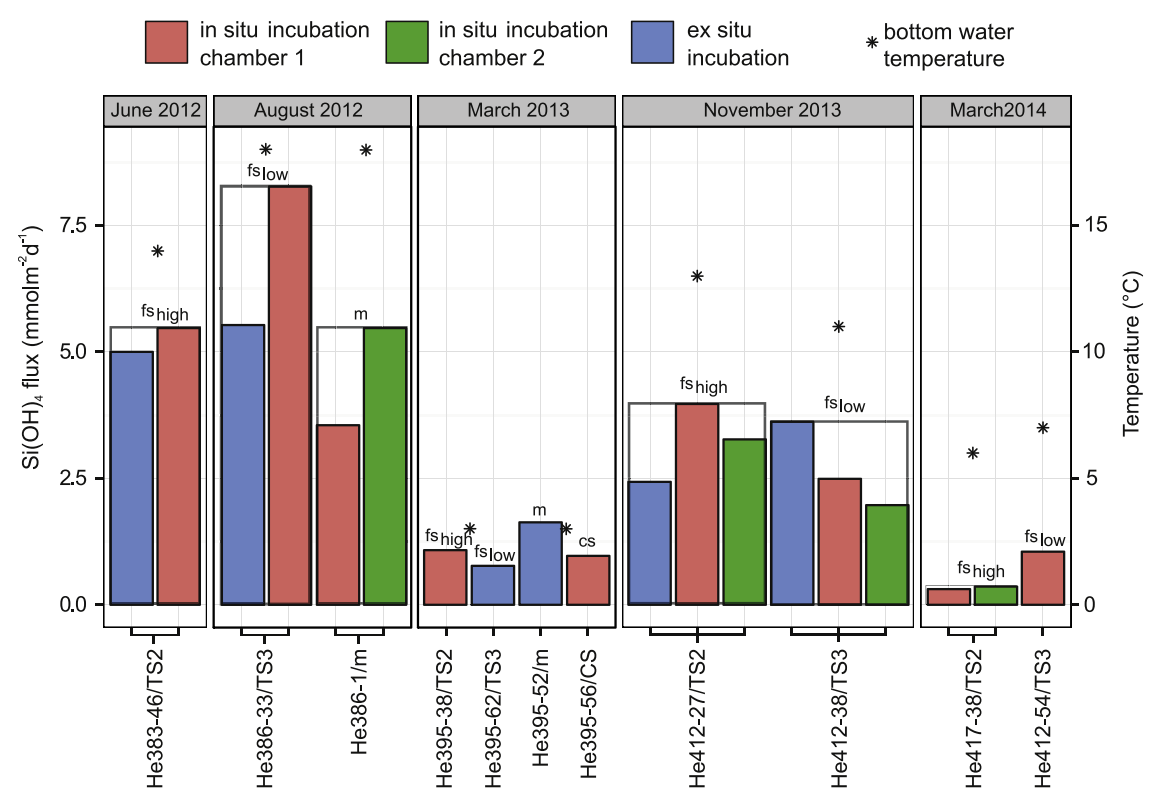

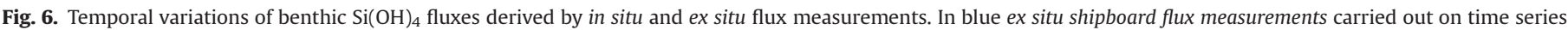

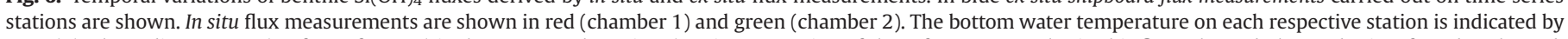

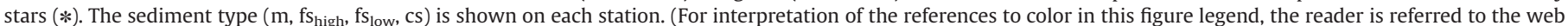
version of this article.) 
Table 2

Estimates about the recycling efficiency of silicic acid and the total rain rate of biogenic silica reaching the sediment.

\begin{tabular}{|c|c|c|c|c|}
\hline Sed. type (1) & $\begin{array}{l}b S i_{a c c}(2) \\
\left(m o l m^{-2} y r^{-1}\right)\end{array}$ & $\begin{array}{l}\mathrm{Si}(\mathrm{OH})_{4 \text { efflux }}(3) \\
\left(\mathrm{mol} \mathrm{m} \mathrm{m}^{-2} \mathrm{yr}^{-1}\right)\end{array}$ & $\begin{array}{l}b S i_{\text {rain }}(4) \\
\left(m o l m^{-2} y r^{-1}\right)\end{array}$ & $\begin{array}{l}\text { Recycling. (5) } \\
(\%)\end{array}$ \\
\hline $\mathrm{m}$ & 0.9 & $\begin{array}{l}1.3 \\
(\min 0.6, \max 2.0)\end{array}$ & $\begin{array}{l}2.2 \\
(\min 1.4, \max 2.9)\end{array}$ & 60 \\
\hline fs ${ }_{\text {high }}$ & 0.7 & $\begin{array}{l}1.1 \\
(\min 0.1, \max 2.00)\end{array}$ & $\begin{array}{l}1.9 \\
(\min 0.8, \max 2.7)\end{array}$ & 61 \\
\hline fs $_{\text {low }}$ & 0.7 & $(\min 0.3, \max 3.0)$ & $\begin{array}{l}1.7 \\
(\min 0.9, \max 3.7)\end{array}$ & 60 \\
\hline cs & 0.4 & $\begin{array}{l}1.6 \\
(\min 0.5, \max 3.7)\end{array}$ & $\begin{array}{l}2 \\
(\min 0.8, \max 4.1)\end{array}$ & 81 \\
\hline
\end{tabular}

Column (1) sediment type, (2) bSi accumulation rate ( $\mathrm{bSi}_{\mathrm{acc}}$ ), (3) $\mathrm{Si}(\mathrm{OH})_{4}$ efflux along the sediment water interface based on seasonal averaged values,

(4) bSi rain rate, and (5) benthic recycling efficiency of bSi $\left(\mathrm{Si}(\mathrm{OH})_{4}\right.$ efflux $/ \mathrm{bSi}$ rain rate*100).

Assuming sedimentation rates of $0.0026 \mathrm{~m} \mathrm{yr}^{-1}$ (Hebbeln et al., 2003) we calculated the mass accumulation of biogenic silica (Eq. (2); Table 2, column 2). For this purpose, we applied the average biogenic silica content and porosity for each sediment type, since the content of biogenic silica as well as grain size distribution or porosity did not show major variations over the period of investigation (Table 1). For muddy $(\mathrm{m})$ and fine sand deposits ( $\mathrm{fs}_{\text {high, }}$, $\mathrm{fs}_{\text {low }}$ ) we calculated almost similar bSi accumulation rates of $0.7-0.9 \mathrm{~mol} \mathrm{~m}^{-2} \mathrm{yr}^{-1}$. In contrast, the bSi mass accumulation in coarse sand sediments (cs) of $0.4 \mathrm{~mol} \mathrm{~m}^{-2} \mathrm{yr}^{-1}$ is considerably lower (Table 2, column 2). In coarse grained sediments bSi might dissolute rapidly, while an advective solute exchange reduces the accumulation of $\mathrm{Si}(\mathrm{OH})_{4}$ in the pore water (Ehrenhauss et al., 2004).

To quantify the total rain rate of bSi reaching the seafloor, the efflux of silicic acid through the sediment water interface has to be considered. This quantity reflects the amount of bSi dissolved within the sediments. In contrast to the sediment composition, the efflux of silicic acid showed considerable temporal variations as discussed before (Fig. 6). Based on in situ and ex situ incubations, we calculated a weighted average efflux of $\mathrm{Si}(\mathrm{OH})_{4}$ as well as minimum and maximum efflux rates with respect to the seasonal cycle (Table 2, column 3). Within the target area, the calculated bSi rain rates (Table 2, column 4) are comparatively similar (average $1.7-2.2 \mathrm{~mol} \mathrm{~m}^{-2} \mathrm{yr}^{-1}$ ) for the different sediment types. This seems likely, since local differences in primary production in surface waters within the study area of about $2270 \mathrm{~km}^{2}$ are not to be expected. Based on benthic flux data and the burial of bSi, we calculated a mass budget for the whole area of investigation by multiplying each flux with the spatial coverage $\left(\mathrm{km}^{2}\right)$ of the respective sediment type and summing up all fluxes. This results in a total rain rate of biogenic silica $\left(\mathrm{bSi}_{\text {rain }}\right.$ rate) of $3.8 * 10^{9} \mathrm{~mol} \mathrm{yr}^{-1}$ (min $2.0 * 10^{9} \mathrm{~mol} \mathrm{yr}^{-1}, \max 7.8 * 10^{9} \mathrm{~mol} \mathrm{yr}^{-1}$ ) for the entire area under investigation.

The efficiency of different sediment types to recycle biogenic silica is shown in Table 2 (column 5). In coarse grained sediments a fraction of about $81 \%$ of the deposited biogenic silica is transported back into the water column. Considerably lower recycling efficiencies (60-61\%) were observed in the fine grained sediments. This suggests that in coarse grained sediments biogenic opal is efficiently recycled, whereas in finer grained sediments higher amounts of biogenic silica are preserved. Lower preservation efficiencies in permeable sediments might be caused by higher dissolution rates and effluxes due to advective transport processes such as bioirrigation or wave induced pore water flushing (Vanderborght et al., 1977; Huettel et al., 2014).

A high bSi flux to the sediment, coupled with a high reflux of silicic acid suggests a strong benthic-pelagic coupling within the southern German Bight. The reactivity of the fresh phytoplankton is several orders of magnitude higher compared to altered biogenic silica and can be further enhanced by the removal of organic or inorganic coatings (Rickert et al., 2002). High dissolution rates and a high faunal induced transport of silicic acid might cause a net reflux of silicic acid at the sediment water boundary and a comparatively low accumulation of bSi in the sediment. Biogenic silica settling at the sediment water interface might directly recycle at the sediment-water interface and therefore not accumulate within the top most centimetres of the sediments. BSi recycling efficiencies of different sediment types support ecosystem models, as the rain rate of bSi to the sediment and the timing of the efflux of silicic acid from the sediment into the water column might be identified.

\section{Conclusion}

In situ flux measurements with the benthic lander NuSObs, ex situ flux measurements as well as sediment and pore water studies indicate that the silica cycle of the southern German Bight (North Sea) is highly dynamic over seasonal cycles. In situ flux measurements suggest considerable temporal variations with highest silicic acid effluxes in summer (June and August) and autumn (November) (2.0-8.3 mmol m $\left.\mathrm{m}^{-2} \mathrm{~d}^{-1}\right)$ and lowest effluxes in winter (March) (0.3-1.1 mmol m-2 $\left.\mathrm{d}^{-1}\right)$. Flux rates correlate with the bottom water temperature and seem to be controlled by a combination of abiotic processes (diffusion, solubility) and benthic macrofauna. High benthic effluxes of silicic acid in June and August might follow the deposition of spring diatom blooms in the second half of April (Radach et al., 1990).

Mass budget calculations indicate bSi fluxes of about 1.7$2.2 \mathrm{~mol} \mathrm{Si} \mathrm{m}^{-2} \mathrm{yr}^{-1}$ from the water column to the sediment. These flux rates are about 10 folds higher than in regions like the North Atlantic, the North Pacific or the Indian Ocean (Tréguer and De La Rocha, 2013). Only major accumulation areas of biogenic silica such as the Opal belt of the Southern Ocean show similar rain rates. However biogenic silica contents of surface sediments are rather low (0.2$3.7 \mathrm{wt} \%)$ and similar to other coastal areas such as the Amazon shelf ( 0.2-0.4 wt\%, DeMaster et al., 1983) or the Monterey Bay ( $<1 \mathrm{wt} \%$, Berelson et al., 2003). The low bSi contents, in conjunction with high effluxes of silicic acid, indicate that the shallow German Bight is characterized by a close benthic-pelagic coupling, due to settling of highly reactive biogenic material and a high reflux of silicic acid.

\section{Acknowledgments}

We thank the crews of RV Heincke for close collaboration during research cruises; Roi Martinez, Ingrid Stimac, Ingrid Dohrmann, Ludmilla Baumann, Rita Fröhlking and Petra Nehmer for technical and analytical assistance; Christian Winter for sediment grain size analyses. Michiel Rutgers van der Loeff and Justus van Beusekom are thanked for critical comments on the manuscript. This study was supported by the Helmholtz-Zentrum Geesthacht Institut für Küstenforschung through the COSYNA project (Coastal Observing Systems for Northern and Arctic Seas) and the NOAH project funded by the BMBF. 
Table A1

Dominant macrofauna species based on mean abundance (Ind./0.007 $\mathrm{m}^{2}$ ) that contributed (Contrib\%) most to the community structure of each station. Feeding types: $\mathrm{SF}=$ suspension feeder, $\mathrm{SSD}=$ subsurface deposit feeder, $\mathrm{P}=$ predator, $\mathrm{IF}=$ interface feeder, $\mathrm{O}=$ omnivorous, $\mathrm{SD}=$ deposit feeder. Functional types: $\mathrm{S}=$ surficial modifier, $\mathrm{B}=$ biodiffuser, $\mathrm{UC}=$ upward conveyor, $\mathrm{UC} / \mathrm{DC}=$ upwarddownward conveyor.

\begin{tabular}{|c|c|c|c|c|}
\hline Species & $\begin{array}{l}\text { Mean abundance } \\
\text { (Ind./0.007 } \mathbf{~ m}^{2} \text { ) }\end{array}$ & Contrib\% & $\begin{array}{l}\text { Feeding } \\
\text { type }\end{array}$ & $\begin{array}{l}\text { Functional } \\
\text { type }\end{array}$ \\
\hline \multicolumn{5}{|l|}{ Cruise HE395 } \\
\hline \multicolumn{5}{|l|}{ Station 39/TS2 } \\
\hline \multicolumn{5}{|l|}{ Month March } \\
\hline $\begin{array}{l}\text { Kurtiella } \\
\text { bidentata }\end{array}$ & 7.75 & 21.19 & SF & $\mathrm{S}$ \\
\hline Nucula nitidosa & 7.25 & 18.63 & SSD & $\mathrm{S}$ \\
\hline Pholoe baltica & 5.25 & 14.55 & $\mathrm{P}$ & $\mathrm{S}$ \\
\hline $\begin{array}{l}\text { Scoloplos } \\
\text { armiger }\end{array}$ & 3.25 & 8.27 & SSD & $\mathrm{B}$ \\
\hline Capitellidae juv. & 3 & 7.79 & SSD & UC \\
\hline $\begin{array}{l}\text { Amphiura } \\
\text { filiformis }\end{array}$ & 2.5 & 5.45 & IF & B \\
\hline $\begin{array}{l}\text { Spiophanes } \\
\text { bombyx }\end{array}$ & 2.75 & 4.97 & IF & $\mathrm{UC} / \mathrm{DC}$ \\
\hline \multicolumn{5}{|l|}{ Cruise HE412 } \\
\hline \multicolumn{5}{|l|}{ Station 28/TS2 } \\
\hline \multicolumn{5}{|l|}{ Month } \\
\hline $\begin{array}{l}\text { Kurtiella } \\
\quad \text { bidentata }\end{array}$ & 24.67 & 23.16 & SF & $\mathrm{S}$ \\
\hline Capitellidae juv. & 12.33 & 15.14 & SSD & UC \\
\hline Ophiuridae juv. & 8.67 & 10.6 & $\mathrm{O}$ & $\mathrm{S}$ \\
\hline Abra nitida & 7.33 & 9.23 & SD & $\mathrm{S}$ \\
\hline $\begin{array}{l}\text { Scalibregma } \\
\text { inflatum }\end{array}$ & 7 & 5.95 & SSD & B \\
\hline Nucula nitidosa & 5.67 & 5.5 & SSD & $\mathrm{S}$ \\
\hline $\begin{array}{l}\text { Spiophanes } \\
\text { bombyx }\end{array}$ & 5 & 5.5 & IF & UC/DC \\
\hline \multicolumn{5}{|l|}{ Cruise HE417 } \\
\hline \multicolumn{5}{|l|}{ Station 39/TS2 } \\
\hline \multicolumn{5}{|l|}{ Month March } \\
\hline $\begin{array}{l}\text { Kurtiella } \\
\text { bidentata }\end{array}$ & 27.75 & 73.95 & SF & $S$ \\
\hline Nucula nitidosa & 3 & 19.88 & SSD & $\mathrm{S}$ \\
\hline Nephtys spp. & 0.5 & 3.92 & $\mathrm{P}$ & $\mathrm{B}$ \\
\hline $\begin{array}{l}\text { Amphiura } \\
\text { filiformis }\end{array}$ & 1.15 & 1.52 & IF & $\mathrm{B}$ \\
\hline
\end{tabular}

\section{Appendix A}

See Table A1.

\section{References}

Aller, R. 1982. The effects of macrobenthos on chemical properties of marine sediment and overlying water. In: McCall, P., Tevesz, J. (Eds.), Animal-Sediment Relations. Plenum Press, New York, pp. 53-102.

Aller, R., Yingst, J., 1985. Effects of the marine deposit-feeders Heteromastus filiformis (Polychaeta), Macoma balthica (Bivalvia), and Tellina texana (Bivalvia) on averaged sedimentary solute. J. Mar. Res. 31, 615-645.

Aller, R.C., 1980. Quantifying solute distributions in the bioturbated zone of marine sediments by defining an average microenvironment. Geochim. Cosmochim. Acta 44, 1955-1965.

Amo, Y., Del, B., Quéguiner, P., Tréguer, H., Breton, Lampert, L., 1997. Impacts of high-nitrate freshwater inputs on macrotidal ecosystems. II. Specific role of the silicic acid pump in the year-round dominance of diatoms in the Bay of Brest (France). Mar. Ecol. Prog. Ser. 161, 225-237.

Barnett, P., Watson, J., Connelly, D., 1984. A multiple corer for taking virtually undisturbed samples from shelf, bathyal and abyssal sediments. Oceanol. Acta 7 , 399-408.

Berelson, W., McManus, J., Coale, K., Johnson, K., Burdige, D., Kilgore, T., Colodner, D., Chavez, F., Kudela, R., Boucher, J., 2003. A time series of benthic flux measurements from Monterey Bay, CA. Cont. Shelf Res. 23, 457-481.

Berner, R.A., 1980. Early Diagenesis: A Theoretical Approach, 1st ed Princeton University press.
Bidle, K., Azam, F., 1999. Accelerated dissolution of diatom silica by marine bacterial assemblages. Nature, 508-512.

Boudreau, B.P., 1997. Diagenetic Models and Their Implementation. Springer, Berlin. Breitzke, M., 2006. Physical Properties of Marine Sediments. Springer, Berlin Heidelberg, pp. 27-71.

Brockmann, U., Eberlein, K., 1986. River input of nutrients into the German Bight. In: Stig Skreslet (Ed.), The Role of Freshwater Outflow in Coastal Marine Ecosystems. Springer, Berlin Heidelberg, pp. 231-240.

Chauvaud, L., Jean, F., Ragueneau, O., Thouzeau, G., 2000. Long-term variation of the Bay of Brest ecosystem: benthic-pelagic coupling revisited. Mar. Ecol. Prog. Ser. 200, 35-48.

DeMaster, D.J., 2002. The accumulation and cycling of biogenic silica in the Southern Ocean: revisiting the marine silica budget. Deep Sea Res. II: Top. Stud. Oceanogr. 49, 3155-3167.

DeMaster, D.J., Knapp, G.B., Nittrouer, C.A., 1983. Biological uptake and accumulation of silica on the Amazon continental shelf. Geochim. Cosmochim. Acta 47, 1713-1723.

Dixit, S., Van Cappellen, P., van Bennekom, A.J., 2001. Processes controlling solubility of biogenic silica and pore water build-up of silicic acid in marine sediments. Mar. Chem. 73, 333-352.

Dominik, J., Förstner, U., Mangini, A., Reineck, H.E., 1978. 210Pb and 137Cs chronology of heavy metal pollution in a sediment core from the German Bight (North Sea). Senckenberg. Marit. 10, 213-227.

Ehrenhauss, S., Witte, U., Janssen, F., Huettel, M., 2004. Decomposition of diatoms and nutrient dynamics in permeable North Sea sediments. Cont. Shelf Res. 24, 721-737.

Emerson, S., Jahnke, R., Heggie, D., 1984. Sediment-water exchange in shallow water estuarine sediments. J. Mar. Res. 42, 709-730.

Fauchald, K., Jumars, P., 1979. The diet of worms: a study of polychaete feeding guilds. Oceanogr. Mar. Biol. Annu. Rev. 17, 193-284.

Figge K., 1981. Erläuterungen zur Karte der Sedimentverteilung in der Deutschen Bucht 1:250 000 (Karte Nr. 2900).

Forster, S., Glud, R.N., Gundersen, J.K., Huettel, M., 1999. In situ study of bromide tracer and oxygen flux in coastal sediments. Estuar. Coast. Shelf Sci. 49, 813-827.

Gehlen, M., Malschaert, H., Van Raaphorst, W.R., 1995. Spatial and temporal variability of benthic silica fluxes in the southeastern North Sea. Cont. Shelf Res. 15, 1675-1696.

Geibert, W., Rutgers van der Loeff, M.M., Usbeck, R., Gersonde, R., Kuhn, G., SeebergElverfeldt, J., 2005. Quantifying the opal belt in the Atlantic and southeast Pacific sector of the Southern Ocean by means of ${ }^{230} \mathrm{Th}$ normalization. Glob. Biogeochem. Cycles 19. http://dx.doi.org/10.1029/2005GB002465.

Gieskes, W.W.C., van Bennekom, A.J., 1973. Unreliability of the ${ }^{14} \mathrm{C}$ method for estimating primary productivity in eutrophic Dutch coastal waters. Limnol. Oceanogr. 18, 494-495.

Gieskes, W.W.C., Kraay, G.W., 1977. Continuous plankton records: changes in the plankton of the North Sea and its eutrophic southern bight from 1948 to 1975. Netherlands. J. Sea Res. 11, 334-364.

Glud, R.N., 2008. Oxygen dynamics of marine sediments. Mar. Biol. Res. 4, 243-289. Hammond, D.E., Cummins, K.M., McManus, J., Berelson, W.M., Smith, G., Spagnoli, F., 2004. A comparison of methods for benthic flux measurement along the California margin: shipboard core incubations vs. in situ benthic landers. Limnol. Oceanogr. Methods 2, 146-159.

Hebbeln, D., Scheurle, C., Lamy, F., 2003. Depositional history of the Helgoland mud area, German Bight, North Sea. Geo-Mar. Lett. 23, 81-90.

Helder, W., Andersen, F.O., 1987. An experimental approach to quantify biologically mediated dissolved silicate transport at the sediment-water interface. Mar. Ecol. Prog. Ser. 39, 305-311.

Hertweck, G., 1983. Das Schlickgebiet in der inneren Deutschen Bucht. Aufnahme mit dem Sedimentechographen. Senckenberg. Marit. 15, 219-249.

Huettel, M., Berg, P., Kostka, J.E., 2014. Benthic exchange and biogeochemical cycling in permeable sediments. Mar. Sci. 6, 23-51.

Hurd, D.C., 1973. Interactions of biogenic opal, sediment and seawater in the Central Equatorial Pacific. Geochim. Cosmochim. Acta 37, 2257-2282.

Janssen, F., Huettel, M., Witte, U., 2005. Pore-water advection and solute fluxes in permeable marine sediments(II): benthic respiration at three sandy sites with different permeabilities (German Bight, North Sea). Limnol. Oceanogr. 50, 779-792.

Joint, I., Pomroy, A., 1993. Phytoplankton biomass and production in the southern North Sea. Mar. Ecol. Prog. Ser. 99, 169-182.

Lerman, A., 1978. Chemical exchange across sediment-water interface. Annu. Rev. Earth Planet. Sci. 6, 281.

Müller, P.J., Schneider, R., 1993. An automated leaching method for the determination of opal in sediments and particulate matter. Deep Sea Res. I: Oceanogr. Res. Pap. 40, 425-444.

Marinelli, R., 1992. Effects of polychaetes on silicate dynamics and fluxes in sediments: Importance of species, animal activity and polychaete effects on benthic diatoms. J. Mar. Res. 50, 745-779.

Nedwell, D.B., Parkes, R.J., Upton, A.C., Assinder, D.J., 1993. Seasonal fluxes across the sediment-water interface, and processes within sediments. Philos. Trans. R. Soc. Lond. A: Phys. Eng. Sci. 343, 519-529.

Queirós, A.M., Birchenough, S.N.R., Bremner, J., Godbold, J.A., Parker, R.E., RomeroRamirez, A., Reiss, H., Solan, M., Somerfield, P.J., Van Colen, C., Van Hoey, G., Widdicombe, S., 2013. A bioturbation classification of European marine infaunal invertebrates. Ecol. Evol. 3, 3958-3985.

Radach, G., Berg, J., Hagmeier, E., 1990. Long-term changes of the annual cycles of 
meteorological, hydrographic, nutrient and phytoplankton time series at Helgoland and at LV ELBE 1 in the German Bight. Cont. Shelf Res. 10, 305-328.

Ragueneau, O., Chauvaud, L., Moriceau, B., 2005. Biodeposition by an invasive suspension feeder impacts the biogeochemical cycle of $\mathrm{Si}$ in a coastal ecosystem (Bay of Brest, France). Biogeochemistry 75, 19-41.

Ragueneau, O., Varela, E.D., Treguer, P., Queguiner, B., Del amo, Y., 1994. Phytoplankton dynamics in relation to the biogeochemical cycle of silicon in a coastal ecosystem of Western Europe. Mar. Ecol. Prog. Ser. 106, 157-172.

Ragueneau, O., Regaudie-de-Gioux, A., Moriceau, B., Gallinari, M., Vangriesheim, A. Baurand, F., Khripounoff, A., 2009. A benthic Si mass balance on the Congo margin: origin of the $4000 \mathrm{~m}$ DSi anomaly and implications for the transfer of Si from land to ocean. Deep Sea Res. II: Top. Stud. Oceanogr. 56, 2197-2207.

Ragueneau, O., Chauvaud, L., Leynaert, A., Thouzeau, G., Paulet, Y.-M., Bonnet, S. Lorrain, A., Grall, J., Corvaisier, R., Le Hir, M., 2002. Direct evidence of a biologically active coastal silicate pump: ecological implications. Limnol. Oceanogr. 47, 1849-1854.

Rickert, D., Schlüter, M., Wallmann, K., 2002. Dissolution kinetics of biogenic silica from the water column to the sediments. Geochim. Cosmochim. Acta 66, 439-455.

Rutgers van der Loeff, M.M., Anderson, L.G., Hall, P.O., Iversfeldt, A., Josefson, A.B., Sundby, B., Westerlund, S.F.G., 1980. Nutrients in the interstitial waters of the Southern Bight of the North Sea. Netherlands. J. Sea Res. 14, 144-171.

Schlüter, M., Sauter, E., 2000. Biogenic silica cycle in surface sediments of the Greenland sea. J. Mar. Syst. 23, 333-342.

Schlüter, M., Rutgers van der Loeff, M.M., Holby, O., Kuhn, G., 1998. Silica cycle in surface sediments of the South Atlantic. Deep Sea Res. I: Oceanogr. Res. Pap. 45, 1085-1109.

Seeberg-Elverfeldt, J., Schlüter, M., Feseker, T., Kölling, M., 2005. Rhizon sampling of pore waters near the sediment/water interface of aquatic systems. Limnol. Oceanogr. Methods 3, 361-371.

Solan, M., Wigham, D., 2005. Biogenic particle reworking and bacterial-invertebrate interactions in marine sediments. In: Kristensen, E., Haese, R., Kostka, J. (Eds.), Interactions Between Macro- and Microorganisms in Marine Sediments. American Geophysical Union, Wiley and Sons, pp. 105-124.

Ståhl, H., Tengberg, A., Brunnegărd, J., Bjørnbom, E., Forbes, T.L., Josefson, A.B.,
Kaberi, H.G., Hassellöv, I.M.K., Olsgard, F., Roos, P., Hall, P.O.J., 2004. Factors influencing organic carbon recycling and burial in Skagerrak sediments. J. Mar. Res. 62, 867-907.

Sverdrup, H., 1953. On conditions for the vernal blooming of phytoplankton. J. Cons 18, 287-295.

Tengberg, A., Stahl, H., Gust, G., Müller, V., Arning, U., Andersson, H., Hall, P.O.J. 2004. Intercalibration of benthic flux chambers I. Accuracy of flux measurements and influence of chamber hydrodynamics. Prog. Oceanogr. 60, 1-28.

Tréguer, P.J., De La Rocha, C.L., 2013. The world ocean silica cycle. Annu. Rev. Mar. Sci. 5, 477-501.

van Beusekom, J., Diel-Christiansen, S., 2009. Global change and the biogeochemistry of the North Sea: the possible role of phytoplankton and phytoplankton grazing. Int. J. Earth Sci. 98, 269-280.

van Beusekom J., Diel-Christiansen S., 1994. A synthesis of phyto- and zooplankton dynamics in the North Sea environment. WWF - World Wide Fund for Nature. p. 148.

Van Raaphorst, W., Kloosterhuis, H.T., Cramer, A., Bakker, K.J.M., 1990. Nutrient early diagenesis in the sandy sediments of the Dogger Bank area, North Sea: pore water results. Netherlands. J. Sea Res. 26, 25-52.

Vanderborght, J.-P., Wollast, R., Billen, G., 1977. Kinetic models of diagenesis in disturbed sediments. Part 1. Mass transfer properties and silica diagenesis. Limnol. Oceanogr. 22, 787-793.

Viollier, E., Rabouille, C., Apitz, S., Breuer, E., Chaillou, G., Dedieu, K., Furukawa, Y., Grenz, C., Hall, P., Janssen, F., Morford, J., Poggiale, J.-C., Roberts, S., Shimmield, T., Taillefert, M., Tengberg, A., Wenzhöfer, F., Witte, U., 2003. Benthic biogeochemistry: state of the art technologies and guidelines for the future of in situ survey. J. Exp. Mar. Biol. Ecol. 285-286, 5-31.

Von Haugwitz, W., Wong, H.K., Salge, U., 1988. The mud area southeast of Helgoland: a reflection seismic study. Mitt. Geol.-Paläontol. Inst. Univ. Hambg. 65, 409-422.

Witte, U., Pfannkuche, O., 2000. High rates of benthic carbon remineralisation in the abyssal Arabian Sea. Deep Sea Res. II: Top. Stud. Oceanogr. 47, 2785-2804.

Wollast, 1974. The silica problem. In: Goldberg, E.D. (Ed.), The Sea 5. Wiley, pp. 359-392. 